\title{
Determinants of uncontrolled hypertension among clients on anti-retroviral therapy in Kadoma City, Zimbabwe, 2016
}

\author{
Pamela Nyaradzai Magande ${ }^{1 *}$, Daniel Chirundu ${ }^{2}$, Notion Tafara Gombe ${ }^{1}$, More Mungati ${ }^{1}$ and Mufuta Tshimanga ${ }^{1}$
}

\begin{abstract}
Background: Clients on anti-retroviral therapy (ART) are living longer and have risk of hypertension. Side effects of medicines and aging increase this risk. Hypertension prevalence among clients on ART in Kadoma City was estimated to be $30 \%$ in 2015 . Of these, $61 \%$ had uncontrolled hypertension. This was high compared to $46 \%$ of hypertensives in the general population who had uncontrolled hypertension. We determined factors associated with uncontrolled hypertension among clients on ART.
\end{abstract}

Methods: A 1.1 unmatched case control study was conducted. Interviews, anthropometric measurements and record reviews were to collect data on demography and medical history. Epi Info 7 was used for univariate, bivariate analysis and logistic regression.

Results: One hundred and fifty-two cases and 152 controls were recruited into the study. Adding salt to dishes regularly aOR $=5.69$ (3.19-10.16), body mass index (BMI) above $25 \mathrm{~kg} / \mathrm{m}^{2}$ aOR $=2.81(1.60-4.91)$ and history of elevated blood pressure in previous year $\mathrm{aOR}=2.34$ (1.33-4.13) were independent risk factors. Independent protective factors were duration more than 2 years since HIV diagnosis aOR $=0.58(0.35-0.95)$, duration less than 5 years since hypertension diagnosis $\mathrm{aOR}=0.50(0.30-0.83)$ and walking or cycling as a means of transport $\mathrm{aOR}=0$. 27 (0.16-0.48).

Conclusion: Adding salt to dishes regularly, BMl above $25 \mathrm{~kg} / \mathrm{m}^{2}$, history of elevated blood pressure in the previous year, duration more than 2 years since HIV diagnosis, duration less than 5 years since hypertension diagnosis and walking or cycling as a means of transport were independently associated with uncontrolled hypertension. Health education on lifestyle changes like walking and cycling as transport and dietary modification such as salt intake reduction were recommended.

Keywords: Uncontrolled hypertension, ART, Kadoma

\section{Background}

Hypertension and Human Immunodeficiency Virus (HIV) infection are chronic conditions which are asymptomatic and manageable in early stage [1]. The interaction between hypertension and HIV is complex. Renal insufficiency due to HIV infection contributes to secondary hypertension [2-4]. The HIV infected on ART live longer and gain weight. Weight gain is a risk factor of hypertension [1]. The weight gain can be explained in two ways.

\footnotetext{
* Correspondence: pmagande@gmail.com

${ }^{1}$ Department of Community Medicine, University of Zimbabwe, Harare, Zimbabwe

Full list of author information is available at the end of the article
}

The HIV infected when on ART are less susceptible to opportunistic infections that cause malabsorption syndromes. Weight gain can also be a side effect of ART medicines.

ART medicines such as ritonavir-boosted lopinavir (protease inhibitors), efavirenz and tenofovir are associated with hypertension. This is mediated through their side effects. Studies show that insulin resistance precedes lipodystrophy. The slowest step in glucose metabolism transport mediated by glucose transporter -4 (GLUT-4) in muscle and fat. This process is worsened by protease inhibitors $[5,6]$. This results in metabolic syndrome and eventually hypertension. Tenofovir causes renal tubular toxicity 
resulting in renal dysfunction and eventually hypertension when there is pre-existing renal disease [7-9].

Globally, hypertension caused approximately $12.8 \%$ of all deaths in 2012. This accounted for 3.7\% disability adjusted life years (DALYS) in the same year [10]. This is expected to increase due to ageing and population growth [11]. Africa has the highest prevalence of hypertension worldwide. In 2012, the prevalence was reported to be $46 \%$ [10]. This is higher than the global average which is currently $40 \%$ [11]. According to the Zimbabwe STEPwise survey [12], hypertension prevalence was $25 \%$ among adults. No current survey based data exists for Zimbabwe. Hypertension prevalence increased by $40 \%$ between 2013 and 2015 in Kadoma City [13].

At the end of 2014, 36.9 million people were living with HIV worldwide. Sub-Saharan Africa accounts for $70 \%$ of people living with HIV worldwide [14]. In Zimbabwe, approximately 1.6 million people were living with HIV in 2014. Of these, $52 \%$ adults were on ART [15]. In Kadoma City, an estimated 4, 430 people were on ART in 2015 [13]. Although all hypertensives are at risk of uncontrolled hypertension, those who are HIV positive and on ART have higher risk [1-3, 16-18]. Hypertension prevalence of hypertension among clients on ART was estimated to be $30 \%$ at the end of 2015 . Of these, $61 \%$ had uncontrolled hypertension. This was high compared to $46 \%$ of hypertensives in the general population with uncontrolled hypertension. We determined factors associated with uncontrolled hypertension among clients on ART in Kadoma City.

\section{Methods}

A 1:1 unmatched case control study was conducted. A case was defined as a client registered and receiving care at Rimuka Integrated HIV and Tuberculosis Centre (IHTC) with uncontrolled hypertension. A control was defined as a client registered and receiving care at Rimuka IHTC with controlled hypertension. Uncontrolled hypertension was defined as systolic blood pressure greater than $140 \mathrm{mmHG}$ and or diastolic blood pressure $>90 \mathrm{mmHG}$ as defined in the JNC 7 report [19].

Based on a study by Mutede et al. [1], assuming $80 \%$ power, $95 \%$ confidence interval and a case to control ratio of 1:1, with a prevalence of hypertension among clients on anti-retroviral therapy (ART) of $34.9 \%$ and an odds ratio of 2.0 for those who had BMI $>25 \mathrm{~kg} / \mathrm{m}^{2}$, using Fleiss formula, the calculated sample size was 147 cases and 147 controls.

Hypertensive clients on ART who came to IHTC for reviews during the study period were recruited until the sample size was reached. Structured questionnaires were used to collect data on demographics and factors associated with uncontrolled hypertension. The Zimbabwe STEPwise survey 2005 and the World Health Organization
Hypertension questionnaires were adapted to make questionnaires [12, 20]. Anthropometric measurements were conducted as described in the Zimbabwe STEPwise survey [12].

Blood pressure measurements were done using an electronic sphygmomanometer calibrated against a standard mercury sphygmomanometer. At least two readings were made for each client. The time between readings was at least two minutes. The presence of a difference of $10 \mathrm{mmHg}$ or more between the first two readings warrantied a third reading. The final record was the mean of two readings with less than a 10mmHG difference. Those with systolic blood pressure $>140 \mathrm{mmHg}$ and or diastolic blood pressure $>90 \mathrm{mmHg}$ while on treatment were classified as having uncontrolled hypertension according to the JNC 7 report and the CDC definitions. The ascertainment of whether a client is truly a case was done based on the previous two or three blood pressure readings as recorded in the medical records. Adherence to medicines was measured by way of pill counts and client reports.

Medical records reviewed to collect data on medical history. Epi Info $7^{\text {to }}$ (CDC, 2012) was used to perform univariate and bivariate analysis. To identify independent factors, backward logistic regression using the same software was performed. Adjusted odds ratios (aOR) were then reported after the logistic regression. All variables with a $p$ value $<0.05$ were considered statistically significant.

\section{Results}

\section{Demographic characteristics}

One hundred and fifty-two cases and 152 controls were recruited. The cases and the controls were comparable with regards to age group, marital status, education and employment (Table 1). The respondents were also comparable with regards to the medicines they were taking (Table 2).

\section{Physical measurements}

The cases and the control were comparable with regards to weight and height but not with regards to blood pressure (Table 3).

\section{Socio-demographic Factors Associated with Uncontrolled Hypertension}

Earning more than US\$200 (United States dollars), smoking cigarettes, taking alcohol and adding salt to dishes at the time of eating were significant risk factors for uncontrolled hypertension. Being female, walking and cycling regularly and doing active leisure activities were significantly protective against uncontrolled hypertension (Table 4).

\section{Medical Factors Associated with Uncontrolled Hypertension}

The significant medical risk factors for uncontrolled hypertension among clients on ART were; having BMI 
Table 1 Demographic characteristics of the hypertensive clients on ART, Kadoma City, 2016

\begin{tabular}{|c|c|c|c|c|}
\hline \multirow[t]{2}{*}{ Variable } & & \multicolumn{2}{|c|}{ Uncontrolled hypertension } & \multirow[t]{2}{*}{$p$ value } \\
\hline & & Yes n(\%) & No n(\%) & \\
\hline \multicolumn{5}{|c|}{ Age in years } \\
\hline & $\leq 30$ & $10(6)$ & $12(7)$ & \multirow[t]{7}{*}{0.29} \\
\hline & $31-40$ & $19(13)$ & $27(18)$ & \\
\hline & $41-50$ & $61(40)$ & $71(47)$ & \\
\hline & $51-60$ & $45(30)$ & $36(24)$ & \\
\hline & $61-70$ & $15(10)$ & $4(3)$ & \\
\hline & $71-80$ & $2(1)$ & $2(1)$ & \\
\hline & Median age $\left(\mathrm{Q}_{1}=; \mathrm{Q}_{3}=\right)$ & $49\left(Q_{1}=43 ; Q_{3}=54\right)$ & $45\left(Q_{1}=43 ; Q_{3}=52\right)$ & \\
\hline \multicolumn{5}{|l|}{ Sex } \\
\hline & Female & $94(62)$ & $110(72)$ & \multirow[t]{2}{*}{0.051} \\
\hline & Male & $58(38)$ & $42(28)$ & \\
\hline \multicolumn{5}{|c|}{ Marital Status } \\
\hline & Married & $81(53)$ & $80(53)$ & \multirow[t]{6}{*}{0.98} \\
\hline & Widowed & $31(20)$ & $36(24)$ & \\
\hline & Divorced & $28(18)$ & $22(14)$ & \\
\hline & Separated & $9(6)$ & $8(5)$ & \\
\hline & Single & $4(3)$ & $5(3)$ & \\
\hline & Cohabiting & 0 & $1(1)$ & \\
\hline \multicolumn{5}{|c|}{ Education } \\
\hline & Primary & $31(20)$ & $33(22)$ & \multirow[t]{4}{*}{0.14} \\
\hline & Secondary & $106(70)$ & $115(76)$ & \\
\hline & Tertiary & $12(8)$ & $3(2)$ & \\
\hline & None & $3(2)$ & $1(1)$ & \\
\hline \multicolumn{5}{|c|}{ Employment } \\
\hline & Manual & $80(53)$ & $87(57)$ & \multirow[t]{3}{*}{0.84} \\
\hline & Sedentary & $67(44)$ & $56(37)$ & \\
\hline & None & $5(3)$ & $9(6)$ & \\
\hline
\end{tabular}

Table 2 Pharmacological management of hypertensive clients on ART, Kadoma City, 2016

\begin{tabular}{|c|c|c|c|c|}
\hline \multirow[t]{2}{*}{ Medicine } & & \multicolumn{2}{|c|}{ Uncontrolled hypertension } & \multirow[t]{2}{*}{$p$ value } \\
\hline & & Yes n(\%) & No n(\%) & \\
\hline \multirow[t]{6}{*}{ Anti-hypertensives } & Hydrochlorothiazide & $100(66)$ & $114(75)$ & \multirow[t]{6}{*}{0.08} \\
\hline & Atenolol & $17(13)$ & $18(12)$ & \\
\hline & Nifedipine & $13(9)$ & $15(10)$ & \\
\hline & Amlodipine & $12(8)$ & $2(1)$ & \\
\hline & Captopril & $5(3)$ & $2(1)$ & \\
\hline & Other & $3(1)$ & $1(1)$ & \\
\hline \multirow[t]{4}{*}{ Anti-retrovirals } & Tenofovir/Lamivudine/Efevirenz & $144(95)$ & $144(95)$ & \multirow[t]{4}{*}{0.99} \\
\hline & Tenofovir/Lamivudine/Atazanavir & $5(3)$ & $6(4)$ & \\
\hline & Zidovudine/Lamivudine/Atazanavir & $2(1)$ & $2(1)$ & \\
\hline & Tenofovir/Lamivudine/Nevirapine & $1(1)$ & 0 & \\
\hline
\end{tabular}


Table 3 Physical measurements for hypertensive clients on ART, Kadoma City, 2016

\begin{tabular}{|c|c|c|c|}
\hline \multirow[t]{2}{*}{ Variable } & \multicolumn{2}{|l|}{ Uncontrolled hypertension } & \multirow[t]{2}{*}{$p$ value } \\
\hline & Yes n(\%) & No n(\%) & \\
\hline Systolic blood pressure (+/-SD) & $151(+/-15.46)$ & $118(+/-8.91)$ & $<0.05$ \\
\hline Diastolic blood pressure (+/-SD) & $92(+/-9.14)$ & $75(+/-7.05)$ & $<0.05$ \\
\hline \multicolumn{4}{|l|}{ Height in $\mathrm{cm}$} \\
\hline$\leq 150$ & $4(3)$ & $3(2)$ & \multirow[t]{5}{*}{0.68} \\
\hline $151-160$ & $47(31)$ & $62(41)$ & \\
\hline $161-170$ & $82(54)$ & $75(49)$ & \\
\hline $170-180$ & $19(12)$ & $12(8)$ & \\
\hline Median height in $\mathrm{cm}\left(\mathrm{Q}_{1}=; \mathrm{Q}_{3}=\right)$ & $164\left(Q_{1}=160 ; Q_{3}=169\right)$ & $162\left(Q_{1}=158 ; Q_{3}=168\right)$ & \\
\hline \multicolumn{4}{|l|}{ Weight in kg } \\
\hline$\leq 50$ & $8(5)$ & $27(17)$ & \multirow[t]{6}{*}{0.52} \\
\hline $51-60$ & $35(23)$ & $54(36)$ & \\
\hline $61-70$ & $51(34)$ & $43(28)$ & \\
\hline $71-80$ & $37(24)$ & $16(11)$ & \\
\hline $81-90$ & $13(9)$ & $10(7)$ & \\
\hline $91-100$ & $8(5)$ & $2(1)$ & \\
\hline Median weight in $\mathrm{kg}\left(\mathrm{Q}_{1}=; \mathrm{Q}_{3}=\right)$ & $69\left(Q_{1}=61 ; Q_{3}=77\right)$ & $60\left(Q_{1}=54 ; Q_{3}=67\right)$ & \\
\hline \multicolumn{4}{|l|}{ BMl } \\
\hline Underweight & $1(1)$ & $11(7)$ & \multirow[t]{4}{*}{$<0.05$} \\
\hline Normal & $22(15)$ & $10(7)$ & \\
\hline Overweight & $76(50)$ & $107(70)$ & \\
\hline Obese & $52(34)$ & $24(16)$ & \\
\hline Waist circumference $\left(\mathrm{Q}_{1}=; \mathrm{Q}_{3}=\right)$ & $78\left(Q_{1}=71 ; Q_{3}=86\right)$ & $75\left(Q_{1}=71 ; Q_{3}=82\right)$ & \\
\hline
\end{tabular}

above $25 \mathrm{~kg} / \mathrm{m} 2$, a history of elevated hypertension in the previous year, taking anti-hypertensive medicines in the preceding 2 weeks and a family history of hypertension. A waist circumference $<75 \mathrm{~cm}$ and having Stavudine/Lamivudine/Nevirapine as first regimen were significantly protective against uncontrolled hypertension (Table 5).

\section{Independent factors associated with uncontrolled hypertension}

Adding salt to dishes aOR $=5.69(3.19-10.16), \quad B M I \geq$ $25 \mathrm{~kg} / \mathrm{m} 2$ aOR $=2.81(1.60-4.91)$ and history of elevated blood pressure in previous year aOR $=2.34(1.33-4.13)$ were independent risk factors. Independent protective factors were duration $\geq 2$ years since HIV diagnosis $\mathrm{aOR}=0.58(0.35-0.95)$, duration $<5$ years since hypertension diagnosis $\mathrm{aOR}=0.50(0.30-0.83)$ and walking or cycling as a means of transport $\mathrm{aOR}=0.27(0.16-0.48)$.

\section{Discussion}

Adding salt to dishes at time of eating was positively associated with uncontrolled hypertension. Clients who habitually add salt to their dishes have a higher salt content in their dishes. Salt in the body is associated with water retention resulting in high intravascular volumes. This adds the effort that the heart puts into pumping of blood resulting in hypertension. As a result hypertension control becomes poor [21]. This is consistent with a study by Mutede et al. [1] and studies in the general population concluded that high salt intake was associated with uncontrolled hypertension [16-18].

Clients doing well on ART are no longer susceptible to opportunistic infections that cause malabsorption syndromes. While weight gain in a client on ART is a good sign of responding to therapy, there is need for close monitoring. High BMI due to sustained weight gain is associated with metabolic syndrome. Metabolic syndrome is a precursor to conditions such as diabetes mellitus and hypertension due to insulin resistance $[5,6]$. This finding is consistent with studies by Thiebaut et al. [22], Baekken et al. [23], Malaza et.al [24] and De Socio et al. [25] who reported a positive association between hypertension and higher BMI. This presents the need for on-going dialogue with clients to encourage healthy lifestyles and avoiding excess weight gain.

Duration since HIV diagnosis $\geq 2$ years was negatively associated with uncontrolled hypertension. This is consistent with De Socio et al. [25]. Immediately after 
Table 4 Socio-demographic factors associated with uncontrolled hypertension among hypertensive clients on ART, Kadoma City, 2016

\begin{tabular}{|c|c|c|c|c|}
\hline \multirow[t]{2}{*}{ Variable } & & \multicolumn{2}{|c|}{$\begin{array}{l}\text { Uncontrolled } \\
\text { hypertension }\end{array}$} & \multirow[t]{2}{*}{$\mathrm{OR}(95 \% \mathrm{Cl})$} \\
\hline & & Yes n(\%) & No n(\%) & \\
\hline \multirow[t]{2}{*}{ Age } & $\geq 40$ & $123(81)$ & $113(74)$ & $1.46(0.85-2.52)$ \\
\hline & $<40$ & $29(19)$ & $39(26)$ & \\
\hline \multirow[t]{2}{*}{ Sex } & female & $94(62)$ & $110(72)$ & $0.62(0.38-1.00)$ \\
\hline & male & $52(38)$ & $42(28)$ & \\
\hline \multirow[t]{2}{*}{ Level of education } & none & $3(2)$ & $1(1)$ & $3.04(0.31-29.56)$ \\
\hline & some & $149(98)$ & $151(99)$ & \\
\hline \multirow[t]{2}{*}{ Type of occupation } & manual & $80(53)$ & $87(57)$ & $0.83(0.53-1.31)$ \\
\hline & sedentary & $72(47)$ & $65(43)$ & \\
\hline \multirow[t]{2}{*}{ Average income } & $\geq 200$ & $61(40)$ & $44(29)$ & $1.65(1.02-2.65)$ \\
\hline & $<200$ & $91(60)$ & $108(71)$ & \\
\hline \multirow[t]{2}{*}{ Smoking cigarettes } & yes & $37(24)$ & $15(10)$ & $2.94(1.54-5.62)$ \\
\hline & no & $115(76)$ & $137(90)$ & \\
\hline \multirow{2}{*}{$\begin{array}{l}\text { Drinking any } \\
\text { alcohol }\end{array}$} & yes & $39(39)$ & $17(22)$ & $2.20(1.33-3.64)$ \\
\hline & no & $113(74)$ & $118(78)$ & \\
\hline \multirow{2}{*}{$\begin{array}{l}\text { Drinking sorghum } \\
\text { beer }\end{array}$} & yes & $44(29)$ & $27(18)$ & $1.89(1.09-3.25)$ \\
\hline & no & $108(71)$ & $125(82)$ & \\
\hline \multirow[t]{2}{*}{ Drinking wine } & yes & $20(13)$ & $8(5)$ & $2.73(1.16-6.40)$ \\
\hline & no & $132(87)$ & $144(95)$ & \\
\hline \multirow[t]{2}{*}{ Drinking lagers } & yes & $57(38)$ & $26(17)$ & $2.91(1.70-4.96)$ \\
\hline & no & $97(62)$ & $126(83)$ & \\
\hline \multirow{2}{*}{$\begin{array}{l}\text { Adding salt to } \\
\text { dishes }\end{array}$} & yes & $123(81)$ & $60(39)$ & $6.50(3.87-10.93)$ \\
\hline & no & $29(19)$ & $92(61)$ & \\
\hline \multirow[t]{2}{*}{$\begin{array}{l}\text { Commonly used } \\
\text { transport }\end{array}$} & $\begin{array}{l}\text { walking and } \\
\text { cycling }\end{array}$ & $106(70)$ & $126(83)$ & $0.48(0.28-0.82)$ \\
\hline & driving & $46(30)$ & $26(17)$ & \\
\hline \multirow[t]{2}{*}{ Leisure activities } & active & $87(57)$ & $105(69)$ & $0.50(0.37-0.96)$ \\
\hline & passive & $65(43)$ & $47(31)$ & \\
\hline
\end{tabular}

diagnosis of HIV, clients have to deal with psychological issues that come about because of having an incurable condition. With time, they start to accept the condition and 'live positively' resulting in better control of the hypertension. It then becomes imperative that the clients receive psychological support to ensure early acceptance and good control of hypertension.

Having less than 5 years after diagnosis of hypertension was negatively associated with uncontrolled hypertension. This result is consistent with Yameogo et al [26]. Having good blood pressure control early on could be as a result of the fact that the clients will have just received the information and are still very aware of the adverse effects of the condition that led to them seeking treatment. This therefore means they are more likely to be adherent to therapy and lifestyle changes. With time,
Table 5 Medical factors associated with uncontrolled hypertension among hypertensive clients on ART, Kadoma City, 2016

\begin{tabular}{|c|c|c|c|c|}
\hline \multirow[t]{2}{*}{ Variable } & & \multicolumn{2}{|c|}{$\begin{array}{l}\text { Uncontrolled } \\
\text { hypertension }\end{array}$} & \multirow[t]{2}{*}{ OR(95\% Cl) } \\
\hline & & Yes n(\%) & No n(\%) & \\
\hline \multirow[t]{2}{*}{ BMl } & $\geq 25$ & $75(49)$ & $34(22)$ & $3.38(2.06-5.55)$ \\
\hline & $<25$ & $77(51)$ & $118(78)$ & \\
\hline \multirow[t]{2}{*}{ Waist circumference } & $<75 \mathrm{~cm}$ & $10(7)$ & $14(9)$ & $0.60(0.38-0.95)$ \\
\hline & $\geq 75 \mathrm{~cm}$ & $142(93)$ & $138(91)$ & \\
\hline \multirow{2}{*}{$\begin{array}{l}\text { Duration since } \\
\text { hypertension diagnosis }\end{array}$} & $<5$ & $95(63)$ & $108(71)$ & $0.68(0.42-1.10)$ \\
\hline & $\geq 5$ & $57(37)$ & $44(29)$ & \\
\hline \multirow{2}{*}{$\begin{array}{l}\text { Being on } \\
\text { hydrochlorothiazide }\end{array}$} & yes & $100(66)$ & $114(75)$ & $0.64(0.39-1.05)$ \\
\hline & no & $52(34)$ & $38(25)$ & \\
\hline \multirow[t]{2}{*}{ Being on amlodipine } & yes & $12(8)$ & $2(1)$ & $6.43(1.41-29.23)$ \\
\hline & no & $140(92)$ & $150(99)$ & \\
\hline \multirow{2}{*}{$\begin{array}{l}\text { Elevated blood pressure } \\
\text { in last year }\end{array}$} & yes & $87(57)$ & $40(26)$ & $3.75(2.31-6.08)$ \\
\hline & no & $65(43)$ & $112(74)$ & \\
\hline \multirow{2}{*}{$\begin{array}{l}\text { Taking anti- } \\
\text { hypertensives } \\
\text { in last } 2 \text { weeks }\end{array}$} & yes & $114(75)$ & $95(63)$ & $1.80(1.09-2.96)$ \\
\hline & no & $38(25)$ & $57(37)$ & \\
\hline \multirow{2}{*}{$\begin{array}{l}\text { Always having anti- } \\
\text { hypertensives }\end{array}$} & yes & $112(74)$ & $94(62)$ & $1.73(1.06-2.81)$ \\
\hline & no & $40(26)$ & $58(38)$ & \\
\hline \multirow{2}{*}{$\begin{array}{l}\text { Duration since HIV } \\
\text { diagnosis }\end{array}$} & $\geq 2$ & $79(52)$ & $91(60)$ & $0.73(0.46-1.14)$ \\
\hline & $<2$ & $73(48)$ & $61(40)$ & \\
\hline \multirow[t]{2}{*}{ Duration on ART } & $<2$ & $80(53)$ & $89(59)$ & $0.79(0.59-1.24)$ \\
\hline & $\geq 2$ & $72(47)$ & $63(41)$ & \\
\hline \multirow[t]{2}{*}{ Current CD4+ count } & $<500$ & $57(43)$ & $61(46)$ & $0.87(0.54-1.42)$ \\
\hline & $\geq 500$ & $76(57)$ & $71(54)$ & \\
\hline \multirow{2}{*}{$\begin{array}{l}\text { Currently on } \\
\text { Tenolam/Efavirenz }\end{array}$} & yes & $144(95)$ & $144(95)$ & $1.00(0.37-2.74)$ \\
\hline & no & $8(5)$ & $8(5)$ & \\
\hline \multirow{2}{*}{$\begin{array}{l}\text { Currently on } \\
\text { Tenolam/Atazanavir }\end{array}$} & yes & $5(3)$ & $6(4)$ & $0.83(0.25-2.77)$ \\
\hline & no & $147(97)$ & $146(96)$ & \\
\hline \multirow[t]{2}{*}{ Previously on Stalanev } & yes & $23(15)$ & $37(24)$ & $0.55(0.31-0.99)$ \\
\hline & no & $129(85)$ & $115(76)$ & \\
\hline \multirow{2}{*}{$\begin{array}{l}\text { Previously on } \\
\text { Tenolam/Nevirapine }\end{array}$} & yes & $30(20)$ & $18(12)$ & $1.83(0.97-3.45)$ \\
\hline & no & $124(80)$ & $134(88)$ & \\
\hline \multirow{2}{*}{$\begin{array}{l}\text { Family history of } \\
\text { hypertension }\end{array}$} & yes & $108(71)$ & $91(60)$ & $1.65(1.02-2.65)$ \\
\hline & no & $44(29)$ & $61(40)$ & \\
\hline \multirow{2}{*}{$\begin{array}{l}\text { Family history of } \\
\text { stroke }\end{array}$} & yes & $24(16)$ & $14(9)$ & $1.85(0.92-3.73)$ \\
\hline & no & $128(84)$ & $138(91)$ & \\
\hline
\end{tabular}

they become used to the condition and are no longer 'worried' so they then tend to forget. It is therefore important to encourage adherence to medicines and lifestyle changes.

We also found that those who always had their antihypertensive medicines and those who reported having taken their medicines in the preceding 2 weeks were 
more likely to have uncontrolled hypertension. Always having medicines implies good access to them and would be expected to result in the taking of the medicines and good control of hypertension. It is possible that the clients who had the medicines were not necessarily taking them. This could be because of side effects or not perceiving the medicines to be important. At the same time, medicine dosages may have been inadequate. This is an area that was not adequately addressed in this study and would require further investigation.

'White coat hypertension' cannot be ruled out since this was health centre based. Some of the variables were recorded basing on the information reported by the clients. Information bias cannot be ruled out. No laboratory investigations were done due to financial constraints and this a limitation in this study.

\section{Conclusions}

Having no education, being above 40 years of age, smoking, drinking alcohol (sorghum beer, lagers and wines), and adding salt regularly to dishes were socio-demographic risk factors for uncontrolled hypertension among hypertensives on ART. Being female, doing manual work, walking and cycling were socio-demographic protective factors against uncontrolled hypertension. The significant medical risk factors for uncontrolled hypertension among clients on ART were; having BMI above $25 \mathrm{~kg} / \mathrm{m}^{2}$, a history of elevated hypertension in the previous year, taking antihypertensive medicines in the preceding 2 weeks and a family history of hypertension. Having a waist circumference less than $75 \mathrm{~cm}$ and having Stavudine/Lamivudine/ Nevirapine as the first regimen were significant protective factors against uncontrolled hypertension.

Adding salt to dishes, a history of elevated blood pressure in the previous year, $\mathrm{BMI}>25$, duration since HIV diagnosis $\geq 2$ years, duration since hypertension diagnosis $<5$ years and walking or cycling as a means of transport were independently associated with uncontrolled hypertension. Health education on lifestyle changes like walking and cycling as transport and dietary modification such as salt intake reduction were recommended.

\section{Abbreviations \\ ART: Anti-retroviral therapy; ARV: Anti-retroviral; BMI: Body mass index; BP: Blood pressure; CD4: Cluster of differentiation; CDC: Centers for Disease Control and Prevention; DALYS: Disability adjusted life years; GLUT: Glucose transporter; HIV: Human immunodeficiency virus; IHTC: Integrated HIV and Tuberculosis Clinic; JNC 7: Seventh Report of the Joint National Committee on the Prevention, Detection, Evaluation, and Treatment of High Blood Pressure; JREC: Joint Research Ethics Committee for the University of Zimbabwe, College of Health Sciences and the Parirenyatwa Group of Hospitals; MRCZ: Medical Research Council of Zimbabwe; WHO: World Health Organisation}

\section{Acknowledgements}

We are grateful to Kadoma City Council for their support. We are also grateful to the study participants for their cooperation. To the CDC and the Zimbabwe FETP program, thank you for technical assistance.
Funding

Financial support was obtained from Kadoma City Council.

Availability of data and materials

Raw data can be made available on request to the corresponding author.

Authors' contributions

PNM, DC, MM: conception, design, acquisition, data collection, analysis and interpretation of data and drafting the manuscript. MM, NTG, in data analysis and interpretation; MT had oversight of all stages of the research and critically reviewed the final draft for important intellectual content. All authors read and approved the final manuscript.

\section{Authors' information}

Not applicable.

\section{Competing interests}

The authors declare that they have no competing interests both financial and non-financial.

\section{Consent for publication}

Voluntary written informed consent was obtained from all participants for publication of results.

\section{Ethics approval and consent to participate}

Permission to proceed with the study was obtained from Kadoma City Council and the University of Zimbabwe, Department of Community Medicine. Ethical approval was sought from the Joint Research Ethics Committee for the University of Zimbabwe, College of Health Sciences and the Parirenyatwa Group of Hospitals (JREC Ref 157/16) and the Medical Research Council of Zimbabwe (MRCZ/B/1095)

\section{Publisher's Note}

Springer Nature remains neutral with regard to jurisdictional claims in published maps and institutional affiliations.

\section{Author details}

${ }^{1}$ Department of Community Medicine, University of Zimbabwe, Harare, Zimbabwe. ${ }^{2}$ Kadoma City Health Department, Kadoma City, Zimbabwe.

Received: 21 September 2016 Accepted: 28 March 2017

Published online: 04 July 2017

\section{References}

1. Mutede BR, Magure T, Bangure D, Gombe NT, Tshimanga M, Mungati M. Prevalence and factors associated with hypertension among anti-retroviral therapy patients aged 15 Years and above in Makonde District, Zimbabwe, 2012: an analytic cross sectional study. World J Cardiovasc Dis. 2015;5:266-77.

2. Cachay ER. MSD Manual Professional Version, Professional/Infectious Diseases/Human Immunodeficiency Virus (HIV), https://www.merckmanuals. com/professional/infectious-diseases/human-immunodeficiency-virus-(hiv)/ human-immunodeficiency-virus-(hiv)-infection. Accessed 5 Apr 2015.

3. Bloomfield GS, Hogan JW, Keter A, Sang E, Carter EJ, Velazquez EJ, Kimaiyo S. Hypertension and obesity as cardiovascular risk factors among HIV seropositive patients in Western Kenya. PLoS One. 2011;6:22288.

4. Mateen FJ, Kanters S, Kalyesubula R, Mukasa B, Kawuma E, Kengne AP, Mills EJ. Hypertension prevalence and Framingham risk score stratification in a large HIV-positive cohort in Uganda. J Hypertens. 2013;31:1372-8.

5. Grinspoon SK. Metabolic syndrome and cardiovascular disease in patients with human immunodeficiency virus. Am J Med. 2005;118 Suppl 2:23S-8S.

6. Gazzaruso C, Bruno R, Garzaniti A, Giordanetti S, Fratino P, Sacchi P, Filice G. Hypertension among HIV patients: prevalence and relationships to insulin, resistance and metabolic syndrome. J Hypertens. 2003;21:1377-82.

7. Andrew M, Hall AM, Hendry BM, Nitsch D, Connolly JO. Tenofovir-associated Kidney Toxicity in HIV-infected Patients. Am J Kidney Dis. 2011;57(5):773-80.

8. Mpondo BC, Kalluvya SE, Peck RN, Kabangila R, Kidenya BR, Ephraim L, Fitzgerald DW, Downs JA. Impact of antiretroviral therapy on renal function among HIV-infected Tanzanian adults: a retrospective cohort study. PLoS One. 2014;9:89573. 
9. Msango L, Downs JA, Kalluvya SE, Kidenya BR, Kabangila R, Johnson WD Fitzgerald DW, Peck RN. Renal dysfunction among HIV-infected patients starting antiretroviral therapy. AIDS. 2011;25:1421-5.

10. World Health Organisation. Global Health Observatory Data, http://www. who.int/gho/ncd/risk_factors/blood_pressure_prevalence_text/en/. Accessed 25 Apr 2016.

11. Dreisbach AW. Medscape, Epidemiology of Hypertension, http://emedicine. medscape.com/article/1928048-overview\#a2. Accessed 25 Apr 2016.

12. Hakim J, Mujuru N, Rusakaniko S, Gomo ZAR. Zimbabwe NCDs Risk factors Surveillance Report 2005, www.who.int/chp/steps/STEPS_Zimbabwe_Data. pdf. Accessed 25 Apr 2016.

13. Kadoma City Health Surveillance Data, 2015

14. World Health Organisation. Global Observatory Data, HIV/AIDS, http://www. who.int/gho/hiv/en/. Accessed 25 Apr 2016.

15. Ministry of Health and Child Care. Zimbabwe National and Sub-National HIV and AIDS Estimates 2014

16. Schirpenbach C, Reincke M. Epidemiology and etiology of therapy-resistant hypertension. Internist (Berl). 2009;50(1):7-16.

17. Buckley B, Shanahan E, Colwell N, Turgonyi E, Bramlage P, Perry IJ. Blood pressure control in hypertensive patients in Irish primary care practices. $J$ Clin Hypertens (Greenwich). 2009;11(8):432-40.

18. Agyemang C, Bruijnzeels MA, Owusu-Dabo E. Factors associated with hypertension awareness, treatment, and control in Ghana, West Africa. J Hum Hypertens. 2006;20:67-71.

19. Seventh Report of the Joint National Committee on the Prevention, Detection, Evaluation, and Treatment of High Blood Pressure (JNC 7) National High Blood Pressure Education Program, U.S. Department of Health and Human Services, 2003, 03 - 52 3 3, 2-3, https://www.nhlbi.nih.gov/ files/docs/guidelines/express.pdf, Accessed 25 Apr 2016

20. World Health Organisation. Developing Integrated Response of Health Care Systems to Rapid Population Ageing, Patient Questionnaire, Questionnaire for Hypertensive patients, www.who.int/ageing/...one/alc_intra1_ questionnaire_hypertensive.pdf, Accessed 26 Apr 2016.

21. Dovey D. Too Much Salt: How A Diet Too High In Sodium Can Affect Your Heart, Brain, And Even Bone Health, Medical Daily, Vitality, http://www. medicaldaily.com/too-much-salt-how-diet-too-high-sodium-can-affect-yourheart-brain-and-even-bone-330910. Accessed 16 Aug 2016

22. Thiébaut R, El-Sadr WM, Friis-Møller N, Rickenbach M, Reiss P, Monforte AD, et al. Predictors of hypertension and changes of blood pressure in HIVinfected patients. Antivir Ther. 2005;10(7):811-23.

23. Baekken M, Os I, Sandvik L, Oektedalen O. Hypertension in an urban HIVpositive population compared with the general population: influence of combination antiretroviral therapy. J Hypertens. 2008;26(11):2126-33.

24. Malaza A, Mossong J, Barnighausen T, Newell M-L. Hypertension and obesity in adults living in a high HIV prevalence rural area in South Africa. PLoS One. 2012;7(10):47761.

25. De Socio GV, Ricci E, Maggi P, Parruti G, Pucci G, Di Biagio A, et al. Prevalence, awareness, treatment, and control rate of hypertension in HIVinfected patients: the HIV-HY study. Am J Hypertens. 2014;27(2):222-8.

26. Yaméogo NV, Kagambèga L, Millogo RC, Kologo K, Yaméogo AA, Mandi $G D$, et al. Factors associated with poor blood pressure control in hypertensive black Africans: cross-sectional study of 456 hypertensive patients from Burkina Faso. Ann Cardiol Angeiol (Paris). 2012;62(1):38-42.

\section{Submit your next manuscript to BioMed Central and we will help you at every step:}

- We accept pre-submission inquiries

- Our selector tool helps you to find the most relevant journal

- We provide round the clock customer support

- Convenient online submission

- Thorough peer review

- Inclusion in PubMed and all major indexing services

- Maximum visibility for your research

Submit your manuscript at www.biomedcentral.com/submit
Biomed Central 